\title{
Sacred Scripture / Sacred Space
}

\section{The Interlacing of Real Places and Conceptual Spaces in Medieval Art and Architecture. An Introduction}

Thinking about scripture means thinking about space: scripture in its material form occupies space, evolves in space and is virtually bound to the concept of space. There is no imaginable concept of scripture that is not bound to a surface and can get by without interspaces-both are mandatory requirements for the disjunction of characters and therefore necessary for their general decryption. ${ }^{1}$ At the same time, scripture has always possessed a spatial and haptic dimension: scores and engravings ${ }^{2}$ are not just readable, they can also be felt and testify to an intervention by force: in this manner homo scriptor inscribes himself into nature, thereby appropriating and forging his surroundings. In a literal sense, homogenous natural space is transformed into legible cultural space by means of markers-it is virtually molded into a "striated space", characterized by specific legal demands and claims of possession, norms and distinct boundaries. Serving as such markers of cultural space, scripture has always possessed the ability to separate space and determine its quality. Furthermore, complex scriptural systems also have the potential to link 'real' space to imagined and transcendent space, ${ }^{4}$ thereby sometimes reversing the hierarchical order. This certainly can be said of writing and scripture in sacred spaces ("Sakrale Schrifträume”): in Christianity, a so-called "book religion”, virtual space conveyed by 'holy scripture' takes up the primary position and dictates the way real space is understood..$^{5}$ According to biblical understanding, there are no places to which the concept of sacred dignity applies by themselves. ${ }^{6}$ All 'holy' locations-such as the city of Jerusalem, the Mount of Olives or Galilee (galilaea)-are understood to be sanctified

1 Cf. Krämer 2006, 77; Frese 2014, 4 f.

2 For the act of scoring, cf. Berti/Keil/Miglus 2015, 519-531.

3 Cf. Deleuze/Guattari 1987, 523-551. For the metaphorical use of "Pflugschar" (vomer) for "Schreibgriffel” (stilus) in early medieval times cf. Curtius 1948/1967, $317 \mathrm{f}$.

4 Cf. Kiening 2009, 31.

5 For virtual spaces in the Middle Ages in general, cf. Vavra 2005 and 2007. For "holy script”, cf. Luft 2014.

6 Cf. Richter 1998, 249f.

This publication originated in the Collaborative Research Centre 933 "Material Text Cultures. Materiality and Presence of Writing in Non-Typographic Societies" (subproject A05 "Script and Characters on and in the Mediaeval Artwork"). The CRC 933 is funded by the German Research Foundation (DFG). 
by God. ${ }^{7}$ In all of these cases the 'fulfillment' of the prophetic scriptures is of crucial importance. Even the Christian places of worship, the built churches, are only holy in so far as they are serving as a meeting place for the congregation to read the Holy Scripture, to hear the word of God and to celebrate the presence of the divine logos. ${ }^{8}$ Therefore "sacred space" in Christianity is "Sakraler Schriftraum" sui generis.

This claim bears no problem for Christian theology, but presents new challenges to the text-anthropological approach of the fine arts and cultural sciences. Sacred space never occurs in an abstract singular form but is always characterized by a complex overlap of different layers of reality, perception and historical practice. In this context the use of inscriptions has proved to be varied, flexible and multifunctional: Inscriptions can determine and establish sacred space. However, they may also profit from the holiness of a sacred space in a 'parasitic' manner. They are markers and guardians of the border between sacred and profane space, but they can also negate it and make it permeable. ${ }^{9}$ Last but not least, inscriptions can underline and strengthen the architectural skin of a church building but also ascribe a transcendent meaning to its material.

The same can be said for the interiors of sacred space: inscriptions in medieval churches and monasteries are never placed randomly. Their position has been calculated and designed to suit their individual purpose. Inscriptions, by means of a highlighted scriptural appearance, or-on the contrary-hardly visible or readable at all, define thresholds and borderlines (portals, walls and pillars, screens, glass windows), accentuate cultic or liturgical centres (holy graves, sanctuaries, choirs, baptisteries) and point out altars.

The written word in the form of a codex is indispensable for carrying out the liturgy and the reading. As a hidden authentic in reliquaries, it enables the cult and the service at the altar. Founders' inscriptions carry secular procedures into sacred space, either as a narrative or as a quote taken from a document. However, script may also shape sacred space in a nonmaterial way, as a theological concept, as cultural knowledge, as the spoken word or as the sung verse. In this sense, places, furnishings and imagery vested with inscriptions cannot be separated from one another: all of them mark intersections in a complex, multilayered network of theological meaning as well as cultural and socio-cultural actions within the sacred space and its periphery. This network is in constant transition, due to the changes of liturgy on feast days throughout the church year and also due to architectural changes and the donation of new artefacts. Script inside of the network thus also serves to point out different

7 For Jerusalem and the Mount of Olives, cf. Küchler 2014, especially 533-613. For galilaea as the place of encounter with the resurrected Christ and as a theological term, cf. Krüger 2003, especially 265-281. 8 In general cf. Czock 2012; Jäggi 2007.

9 Cf. Kendall 1994 and Gerstel 2006; as well as Favreau 1991. Bawden 2014 on the other hand treats the threshold as a place of image (in German "Bildort”). 
areas within an architectural setting, to form new traffic routes and to accentuate theological meaning.

Exploring "sakrale Schrifträume" means not to study script in sacred space by itself, but instead to investigate its active role in producing sacredness and establishing sacred space. However, these spaces are not to be misunderstood as "vehicles" or "containers" that could basically exist without 'content'. Instead, they are to be comprehended in their relational character ${ }^{10}$-as a meaningful combination of material script artefacts, human practice and theological concepts.

This publication is the result of a congress (Sakrale Schrifträume, November 17November 18, 2016) and a workshop (Reliquie, (In-)Schrift, Raum, May 18-May 19, 2017), both organized by the team of the subproject A05 ("Schrift und Schriftzeichen am und im mittelalterlichen Kunstwerk") of the Collaborative Research Centre 933 "Material Text Cultures" at Heidelberg University and held at the Institute for European Art History in Heidelberg. The case studies presented in this volume offer a wide range of topics and research areas but are, at the same time, linked by the questions that are being examined. These are, on the one hand, the material character and the layout of the inscriptions/scripts, their connection to artefacts, and their visibility and legibility; and, on the other hand, the space containing script, the space referenced by script, and the way in which script serves to generate sacred space.

The first two articles in chronological order are dealing with illuminated manuscripts and focus, from different perspectives, on the codex as a "Schriftraum" ('scripted space'). Art historical research has long since interpreted the illuminated codex as a kind of "sacred space", based on painted elements such as the framing arcades of the canon tables which evoke the idea of architectural space. ${ }^{11}$ In contrast, Tina Bawden examines the method of "interlacing” as a principle of graphic design, taking as a case study St Gallen, Stiftsbibliothek, MS 51, an Irish gospel book from the mid- $8^{\text {th }}$ century. By placing illuminated double pages at the beginning and end of the manuscript and at the beginning of each gospel, the scribe and the illuminist gave the text a visual order. The double pages not only refer to one another, but also to textual passages. Individual pictorial elements are charged with theological meaning. Both referring to the text and its theological content, the illuminated double pages use the method of interlacing to give a semi-spatial structure to the codex, thereby forming a "Schriftraum", even if Bawden does not use this expression explicitly.

Tobias Frese considers the sacramentary of Henry II (München, Bayerische Staatsbibliothek, Clm 4456) from another angle. Instead of taking the entire corpus into account, he focusses on its theological centre, the Canon of the Mass. The fullpage illumination showing the holy sepulchre, which is placed ahead of it, and the initial page (Te igitur) define this part of the corpus as an independent, symbolically

10 Läpple 1991, 189 (in German “relationale Ordnung”).

11 Cf. Reudenbach 2009. 
protected "Schriftraum”. Frese's analysis highlights the subtle relations between the depicted figures, the sepulchre, the framing ornaments and the inscriptions (tituli) and displays in which calculated manner the "script-protected" locus of the miracle of the resurrection corresponds to the shielded "Schriftraum" of the Canon of the Mass. The pictorial arrangement, the inscriptions, the gospel texts to which they allude, and the text of the Canon of the Mass present in the corpus form a tightly-knit reference system: Christ, absent from his grave, is present during the Eucharist; his absence on Easter morning seems to be compensated for by the monumental grave stone. Therefore, both text and image visualize the underlying complex building of theology, a "Schriftraum" surpassing that of the codex and standing behind the process of creation of the miniature, which in fact only becomes comprehensible as a "Kanonbild" within this theological frame of reference.

The following two submissions are dedicated to works of goldsmith's art that are used to store and present relics and therefore play a central role in the cult of saints. In her study of the Borghorst cross from the mid-11 ${ }^{\text {th }}$ century, Elisa Pallottini examines what functions the inscriptions have for the cross as a reliquary. While the inscriptions on the front side, naming the saints and the figures in the donation scene, are hardly visible, the inscription on the back side, made up of larger letters, runs around the entire cross. This inscription names the relics inside of the cross and ends with an invocation of the saints. Though being conspicuous only on the back side, the inscriptions were of utmost importance in order for the cross to 'function': only the inscriptions made the relics visible to the outside and only in naming the saints did worship become possible. Thus, the presence generated by the inscriptions transforms a valuable artefact into the cross-shaped reliquary, enabling the congregation to 'envision' Heavenly Jerusalem in their minds. The "Schriftraum" of the artefact, visualized in the rearward circulating inscription, intermediates with the eschatological space of salvation, the paradise at the end of time.

Marcello Angheben deals with a group of artefacts, the Mosan reliquary shrines, dating from the $11^{\text {th }}$ to the $13^{\text {th }}$ century, thereby focusing on the relation of the shrines to the altar behind which they were installed. Based on the representation of Christus Victor on one of the gable ends, Angheben convincingly argues that the shrines functioned as retables. With the gable end figuring Christus Victor facing the altar, the performance of the priest at the altar during the Eucharist was reflected by this figure which had strong eucharistic connotations. However, for his interpretation of Christus Victor as an image encompassing the theological concept of Christ being the high priest performing the Eucharist and the sacrifice at the same time, Angheben cannot rely on the shrine inscriptions themselves. Instead he points out an iconographical tradition throughout all media, beginning in the $8^{\text {th }}$ and lasting until the $13^{\text {th }}$ century, and links the individual components of the image formula to the "Schrifträume" of the Canon of the Mass and its theological interpretation. Though the shrine inscriptions do not explicitly name the priestly role of Christus Victor, the shrines' location behind the altar with the image of Christus Victor mirroring the priest conveys the idea 
of the unification of the earthly and the heavenly church during the Eucharist, briefly manifesting Heavenly Jerusalem within the church building.

The next set of articles are dedicated to inscriptions on the outside of and within sacred buildings, focusing not only on portal inscriptions and façade inscriptions but also on inscriptions on artefacts within churches and connected areas. Kristina Krüger analyses the role inscriptions played in the church of St Michael's in Hildesheim and its furnishings dating to the $11^{\text {th }}$ century, as far as they can be reconstructed. An examination of the inscriptions in the building and of the artefacts bearing script shows that only few relate to one another. Even the manifold links between some inscriptions, artefacts, and altars show no compelling correlations concerning the artefacts' location or the theological meaning of the inscriptions. However, the significance of single inscriptions or groups of inscriptions and artefacts is broadened substantially when contextualized with the actual liturgical practice, with the Holy Scripture and with scriptural exegesis. The "Schriftraum" of St Michael's can therefore only be understood when set in relation to "Schrifträume" of greater importance and contextualized with the corresponding theological contents and liturgical practices.

Michele Luigi Vescovi examines five large, panel-format inscription plates that were found hors contexte under the pavement of the crypt in the cathedral of Salerno, in the years between 1953 and 1967. The inscriptions name the saints whose relics were transferred to the newly built cathedral by Robert Guiscard, under the guidance of Bishop Alfano. They date back to the year 1081. All plates, except for one, bear round holes (fenestellae confessionis) half way up, meant to enable contact with the relics. Due to the lack of further text sources and archaeological data, Vescovi cannot localize the plates in the modernized interior of the cathedral. The names of the saints carved onto the plates are arranged by category (martyrs, confessors, virgins), bearing resemblance to litanies, and leading Vescovi to localize them near the altars of the crypt. The litanies in honor of local saints would have been recited during a procession to the reliquaries, thereby creating a temporary, acoustic-visual "Schriftraum".

Stefan Trinks describes two different portal arrangements, the access to the castle church of Loarre and the entrance hall of the cathedral of Jaca. They both share a Chrismon relief above the entrance to the sacred space, and Trinks reasons that King Sancho-Ramírez might have been the ordering party of both buildings. As Trinks states, the fragments of a relief frieze above the passageway of the Loarre church, interpreted as images of salvation, the obiit inscription carved into the jambs of the portal leading to the stairs, asking for intercession, and the Chrismon relief above the portal to the lower church, containing several individual initials, are all elements constituting a 'triadic' "Schriftraum", leading to a Demetrios reliquary, which-according to Trinks-was placed on the altar of the lower church, resulting in a sacralisation of the entire castle.

In his study of the $12^{\text {th }}$-century cloister capitals of SS. Pietro ed Orso in Aosta, Wilfried E. Keil deals with inscriptions on the periphery of the sacred space. Central to his argument is a series of capitals in the southern wing, figuring prophets' busts 
with scrolls, which differ from the capitals in the other wings iconographically as well as in a formal manner. The inscriptions on the scrolls cite verses or parts of verses alluding to significant actions or sayings of the represented prophet. Keil assumes that these extracts serve to remind the reader of longer, memorated passages from the respective writings. Notwithstanding all uncertainties concerning the original plan of the surrounding conventual buildings, which are for the most part lost, and the order of the capitals, which was disturbed by restorations, he plausibly argues that the prophets' capitals in the southern wing were not only destined for the canons' edification but instead served for the instruction of the novices that, as far as we know from the customs, took place in the cloister. Therefore Keil interprets the capitals with their verses as loci according to the antique and medieval techniques of memorization. In this perspective the southern wing of the cloister is transformed into a scriptbased "space of learning".

Stefano Riccioni concentrates on epigraphy as an artistic means to express ecclesiastical politics. In the late $11^{\text {th }}$ and $12^{\text {th }}$ century, churches in Rome were enriched by ancient spolia into which contemporary inscriptions were carved. At first, the inscriptions were of small size, placed within the clerics' choir or the sanctuary and designed to be legible from up close. The typeface was adopted from manuscript productions of the Church Reform. When inscriptions also came up on the exterior of churches, on architraves and portal lintels that followed ancient models, the typeface formally remained related to manuscripts and the inscriptions were still only legible at a short distance. During the $12^{\text {th }}$ century, entrance halls were added to many Roman churches. Above the arcades of these entrance halls for the first time inscriptions with large letters conveyed their messages to a broad public. Their typeface was that of rich liturgical manuscripts. These inscriptions, clearly linked to the Church Reform, enabled the supporters of the Reform to extend the "Schriftraum" of the sacred space into the profane public sphere.

Matthias Untermann also examines inscriptions on exterior façades of sacred buildings which sacralize their surroundings. He follows up on façade inscriptions with large letters in the form of a frieze from the $8^{\text {th }}$ century until the $15^{\text {th }}$ century, also including the special case of miniature architectures within church buildings with inscriptions running around the edges. Inscriptions on the exterior always create a sacralized area in front of the building. This effect can be reinforced by artistic means, such as the use of architectural forms stemming from ancient temples, adding extra authority to the sacred message of the text. In contrast, the miniature architectures encircled by inscriptions are meant to ostentatiously mark a special "Schriftraum" within the church building. However, not only do façade inscriptions bear sacred messages, they also contain names of sponsors and mention worldly matters, often indirectly pointing at conflicts. Untermann suggests that the execution of such inscriptions on the exterior of churches was a kind of conflict solution strategy; one could speak of "Schrifträume" of social self-assurance with a connotation of sacredness due to their placement and appearance. 
The two next articles also deal with the merge of worldly matters with sacred space. Wolfgang Christian Schneider examines the pictorial and scriptural programme in the popes' chapel of St Sylvester in SS. Quattro Coronati in Rome. The chapel is part of a mid- $13^{\text {th }}$ century construction that was built as the official residence and 'citadel' for the deputy of the pope who had fled Rome. The frescos covering the chapel's walls were partly lost to later alterations but can be reconstructed in their essentials. They show large-sized episodes from the legend of St Sylvester and the so-called "Donation of Constantine", with the intent to demonstrate the supremacy of the papacy over the empire. Beneath the scenic frescoes a frieze of medallions representing half-figures of the patriarchs and prophets of the Old Testament holding scrolls is today for the most part destroyed. Schneider succeeds to reconstruct the sequence of the busts and inscriptions by using drawings from the $17^{\text {th }}$ century, and by that enables this space of papal self-representation to revive before our eyes. At the same time, the chapel represents a coherently composed space of interrelated script and images, in which the painted verses facilitate recollection of the corresponding bible passages in the mind of the observer, thereby referring to the "Schriftraum" of the Holy Scripture as irrefutable proof of the images' content.

Stefania Gerevini approaches the combination of worldly power and sacred space using the example of the chapel of St Isidor in San Marco in Venice. The chapel of the saint from the Greek island of Chios was built to substantiate Venice's claim to Chios, which was held by the Genovese. It was furnished with a mosaic programme and inscriptions, the most prominent of which refers to the stately and ecclesiastical deputies by name. However, before the consecration of the chapel in 1355, a conspiracy, led by the Doge Marino Falier was uncovered on the day of the translation of the saint, changing the chapel's meaning significantly: from this time on, a yearly procession of the highest deputies of the republic proceeded across the Piazza San Marco, followed by a mass in the chapel, commemorating the foiled coup. Thus, the function of the chapel was changed from being a propaganda instrument against the external enemy to being a commemorative site of the republic's victory over an internal enemy of the state. Or, to say it in a more pronounced way than Gerevini does, a space dedicated to a state-supporting saint's cult was changed into a "Schriftraum" for the cult of the Republic of Venice, forming part of the 'stately' church of San Marco.

In the last paper, Jessica N. Richardson examines two procession banners from the second half of the $14^{\text {th }}$ century, presenting yet another aspect of the topic. Her focus lies on pictures that not only show figures while speaking (the so-called visibile palare) but also reflect certain acts or call for certain acts to take place in front of the picture. The depicted communication on the banner from Sant'Agnese in Bologna is referred to by two painted inscriptions word-for-word. The placement of the inscriptions within the picture visually indicates the speaker and the addressee. Richardson is able to show the similarity of the painted verses to chants in liturgical manuscripts of the Bolognese Dominicans: in all probability these verses were sung like chants by the congregation in front of the banner. The second banner from Montemaggiore near 
Bologna, depicting St Christopher, shows a small painted note, seemingly attached to the banner manually, containing 'instructions' on how to use the picture. Both cases represent pictures with inscriptions demanding that the observer participate. At the same time, both representations of saints painted on cloth were also made to be moved: we are therefore faced with mobile "Schrifträume", whose performative presence was used to carry the sacredness of the ecclesiastical space to the outside.

The gain of substantial insights by the papers of this volume has proven the concept of "sakraler Schriftraum" to be an efficient method of reflecting on the closely interrelated subjects of sacred scripture and sacred space. This term, newly introduced by this publication, is a valid instrument for describing inscriptions and artefacts equipped with script that were consciously placed in a certain order within a sacred space or on its periphery or that were used in performing sacred rites. The term is deliberately chosen to designate at the same time an architectural setting or a pictorial space and the conceptual spaces to which the inscriptions refer-the message of salvation laid down by Holy Scripture, the sacred acts laid down in liturgical codices and the theological discourse manifested in the written word and handed down by it. With this bifold character it sheds light on referencing as a main feature inherent in each inscription, which was clearly understood by the medieval designers of the "Schrifträume" and their contemporary observers but is not always immediately recognized from a modern perspective. Therefore, the concept of "sakraler Schriftraum" provides a more profound understanding of sacred spaces and their liturgical furnishings, allowing essential features of works of art and of the inscriptions which accompany them to be explained for the first time.

For a medieval observer, it was not always necessary to read an inscription from the beginning to the end; instead, it was sufficient for him to recognize individual key words in order to remind him of the corresponding text. Neither was active reading or even the opportunity to do so crucial in all situations; it was enough to know of the presence of the inscriptions and to believe in their efficacy. Decisive for the inscriptions' efficacy was the essentially referential character of script in a sacred context, always referring to Holy Scripture as the "Schriftraum" par excellence-this can even be said of script primarily containing profane content. It is this fundamental reference to Holy Scripture ${ }^{12}$ which made script and/or inscriptions so effective for rendering spaces and actions sacred. The advance of the use of script and literacy in sacred and worldly affairs also promoted the extension of "Schrifträume" into the profane space and their connection with political messages.

12 Cf. Reudenbach 2009. 


\section{Bibliography}

Bawden, Tina (2014), Die Schwelle im Mittelalter. Bildmotiv und Bildort (Sensus. Studien zur mittelalterlichen Kunst 4), Köln / Weimar / Wien.

Becht-Jördens, Gereon (2014), "Schrift im Mittelalter - Zeichen des Heils. Zur inhaltlichen Bedeutung von Material und Form", in: Joachim Friedrich Quack and Daniela Christina Luft (eds.), Erscheinungsformen und Handhabungen heiliger Schriften (Materiale Textkulturen 5), Berlin / Munich/Boston, 245-310.

Berti, Irene/Keil, Wilfried E./Miglus, Peter A. (2015), “Ritzen”, in: Thomas Meier, Michael R. Ott and Rebecca Sauer (eds.), Materiale Textkulturen. Konzepte - Materialien - Praktiken (Materiale Textkulturen 1), Berlin / Munich/Boston, 519-531.

Curtius, Ernst Robert (1948/1967), Europäische Literatur und lateinisches Mittelalter, 6. Aufl., Bern/ München.

Czock, Miriam (2012), Gottes Haus. Untersuchungen zur Kirche als heiligem Raum von der Spätantike bis ins frühe Mittelalter (Millennium-Studien zu Kultur und Geschichte des ersten Jahrtausends n. Chr. 38; Diss. Bochum 2009), Berlin / Boston.

Deleuze, Gilles / Guattari, Félix (1980/1987), Mille Plateaux (Capitalisme et Schizophrénie Vol. II), Paris 1980. Engl. Edition: A Thousand Plateaux (Capitalism and Schizophrenia Vol. II). Translation and Foreword by Brian Massumi. London / New York 1987.

Favreau, Robert (1991), “Le thème épigraphique de la porte”, in: La façade romane (Actes du colloque international, CESCM, Poitiers, 26-29 septembre 1990), Cahiers de civilisation médiévale, 267-279.

Frese, Tobias (2014), “'Denn der Buchstabe tötet’ - Reflexionen zur Schriftpräsenz aus mediävistischer Perspektive”, in: Tobias Frese; Wilfried E. Keil and Kristina Krüger (eds.), Verborgen, unsichtbar, unlesbar - zur Problematik restringierter Schriftpräsenz (Materiale Textkulturen 2), Berlin/Boston, 1-15.

Gerstel, Sharon E. J. (ed.) (2006), Thresholds of the Sacred. Architectural, Art Historical, and Theological Perspectives on Religious Screens, East and West, Dumbartons Oaks.

Jäggi, Carola (2007), “Die Kirche als heiliger Raum: Zur Geschichte eines Paradoxons”, in: Berndt Hamm, Klaus Herbers and Heidrun Stein-Kecks (eds.), Sakralität zwischen Antike und Neuzeit (Beiträge zur Hagiographie 6), Stuttgart, 75-89.

Kendall, Calvin B. (1994), "The Gate of Heaven and the Fountain of Life: Speech-Act Theory and Portal Inscriptions", in: Essays in Medieval Studies 10, 111-128.

Kiening, Christian (2009), "SchriftRäume. Inszenierung und Deutungen der Buchstaben (15001800)”, in: Ingrid Baumgärtner et al. (eds.), Raumkonzepte. Disziplinäre Zugänge, Göttingen, 29-49.

Krämer, Sybille (2006), "Zur Sichtbarkeit der Schrift oder: Die Visualisierung des Unsichtbaren in der operativen Schrift. Zehn Thesen", in: Susanne Strätling and Georg Witte (eds.), Die Sichtbarkeit der Schrift (contributions to the conference "Die Sichtbarkeit der Schrift", Berliner Akademie der Künste, April 2004), Munich, 75-84.

Krüger, Kristina (2003), Die romanischen Westbauten in Burgund und Cluny: Untersuchungen zur Funktion einer Bauform, Berlin.

Küchler, Max (2014), Jerusalem: ein Handbuch und Studienreiseführer zur Heiligen Stadt (Orte und Landschaften der Bibel; Vol. 4,2), 2., completely revised edition, Göttingen.

Läpple, Dieter (1991), “'Essay über den Raum'. Für ein gesellschaftswissenschaftliches Raumkonzept”, in: Hartmut Häußermann et al. (eds.), Stadt und Raum. Soziologische Analysen, Pfaffenweiler, 157-207. 
Luft, Daniela (2014), “Heilige Schriften und ihre Heiligkeit in Umgang und materieller Präsenz”, in: Daniela Luft, Joachim Quack (eds.), Erscheinungsformen und Handhabungen Heiliger Schriften (Materiale Textkulturen 5), Berlin / Boston, 3-38.

Reudenbach, Bruno (2009), “Der Codex als heiliger Raum. Überlegungen zur Bildausstattung früher Evangelienbücher", in: Stephan Müller, Lieselotte E. Saurma-Jeltsch and Peter Strohschneider (eds.), Codex und Raum (Wolfenbütteler Mittelalter-Studien 21), Wiesbaden, 59-84.

Richter, Klemens (1998), “Heilige Räume. Eine Kritik aus theologischer Perspektive”, in: Liturgisches Jahrbuch 48, 249-264.

Vavra, Elisabeth (ed.) (2005), Virtuelle Räume. Raumwahrnehmung und Raumvorstellung im Mittelalter (Akten des 10. Symposiums des Mediävistenverbandes, Krems, 24.-26. März 2003), Berlin.

Vavra, Elisabeth (ed.) (2007), Imaginäre Räume: Sektion B des Internationalen Kongresses "Virtuelle Räume - Raumwahrnehmung und Raumvorstellung im Mittelalter”, Krems 24.-26. März 2003 (Veröffentlichungen des Instituts für Realienkunde des Mittelalters und der Frühen Neuzeit 19), Vienna. 